\title{
$\mathrm{Al}_{2} \mathrm{O}_{3} / \mathrm{CNTs}$ 하이브리드소재의 와이어 방전연삭을 이용한 마이크로 방전기공 특성
}

\author{
탁현석 · 김종훈 · 임한석 ${ }^{*}$ 이춘태 ${ }^{b} \cdot$ 정영근 - 강명창* \\ 부산대학교 하이브리드소재 솔루션 국가핵심연구센터(NCRC), \\ ${ }^{a}$ 하이브리드 정밀회사, ${ }^{b}$ 신라대학교 자동차기계공학과
}

\section{Characteristics of Micro EDM using Wire Electrical Discharge Grinding for $\mathrm{Al}_{2} \mathrm{O}_{3} / \mathrm{CNTs}$ Hybrid Materials}

\author{
Hyun-Seok Tak, Jong-Hun Kim, Han-Suk Lim ${ }^{a}$, Choon-Tae Lee ${ }^{b}$, \\ Young-Keun Jeong, and Myung-Chang Kang* \\ ${ }^{a}$ National Core Research Center for Hybrid Materials Solution, Pusan National University, \\ San 30, Jangjeon-Dong, Geumjeong-Gu, Busan 609-735, Korea \\ ${ }^{b}$ Hybrid Precision Co., Business Incubator Center, Dong Eui University, 995 Eom Gwang-Ro, \\ BusanJin-Gu, Busan 614-714, Korea \\ ${ }^{c}$ Department of Automotive \& Mechanical Engineering, Silla University, San 1-1, \\ Gwaebop-Dong, Sasang-Gu, Busan 617-736, Korea \\ (Received July 12, 2010; Revised July 28, 2010; Accepted August 9, 2010)
}

\begin{abstract}
Electrical discharge machining (EDM) is an attractive machining technique but it requires electrically conductive ceramic materials. In this study, Alumina matrix composites reinforced with CNTs were fabricated through CNT purification, mixing, compaction and spark plasma sintering (SPS) processes. $\mathrm{Al}_{2} \mathrm{O}_{3}$ nanocomposites with the different CNT concentrations were synthesized. The mechanical and electrical characteristics of $\mathrm{Al}_{2} \mathrm{O}_{3} / \mathrm{CNTs}$ composites were examined in order to apply the materials to the EDM process. In addition, micro-EDM using wire electrical discharge grinding (WEDG) was conducted under the various EDM parameters to investigate the machining characteristics of machined hole by Field Emission Scanning Electron Microscope (FE-SEM). The results show that $\mathrm{Al}_{2} \mathrm{O}_{3} / \mathrm{CNTs} 10 \%$ Vol. was more suitable than the other materials because high conductivity and large discharge energy caused violent sparks resulting in bad machining accuracy and surface quality.
\end{abstract}

Keywords : Conductive ceramic, $\mathrm{Al}_{2} \mathrm{O}_{3} / \mathrm{CNTs}$ hybrid composites, Micro EDM, WEDG device

\section{1. 서 론}

알루미나(Alumina)는 일반적으로 고경도, 고열저항 성, 화학적 안정성, 저열전도도 등과 같은 우수한 특 성과 다양한 가능성을 지니고 있고, 고온에서 강도와 강성을 유지하는 특성 때문에 고온용 부품에 있어서 다양하게 활용되고 있으며, 특히 뛰어난 내마모성으
로 실린더 라이너, 부싱, 베어링 같은 부품 등의 소 재로 이용되고 있다. 그러나 가공성이 나빠 제조에 어려움이 있는 것은 물론, 취성으로 인해 그 응용이 크게 제한되고 있다[1]. 최근에는 Carbon nanotubes $(\mathrm{CNTs})$ 를 복합재료에 적용함으로써 인성을 향상 시 키는 연구가 이루어지고 있다[2].

$\mathrm{CNTs}$ 는 나노 크기로서의 특성뿐만 아니라, 우수한

*Corresponding Author : [Tel : +82-51-510-2361; E-mail : kangmc@pusan.ac.kr] 
기계적, 화학적, 열적, 전기적 특성으로 인하여 전자 방출원, 복합재료, 정전기 및 전자파 차폐재, 연료전 지 등 넓은 분야에서 21세기 미래를 주도할 신소재 로 서 각광받고 있다[3]. 특히, CNT는 밀도(약 2.0 $\left.\mathrm{g} / \mathrm{cm}^{3}\right)$ 가 낮고, 높은 탄성계수(E1.8 TPa)를 나타내므 로 $\mathrm{CNT}$ 를 강화재로 사용한 나노복합재료의 개발 가 능성이 기대되고 있다[4].

마이크로 방전가공(Micro-Electrical Discharge Machining)은 미세가공에 있어서 가장 중요한 기술 중 하나이다. Micro-EDM은 전도성을 가진 광범위한 재료를 경도와 무관하게 가공 할 수 있다[5]. 또한 물리적인 힘이 발생하지 않는 비접촉식 가공이므로 가공 후 변형이 작다. 이런 장점은 미세가공에서 복 잡한 형상을 고정밀도로 가공이 가능하므로 널리 이 용되고 있다. 또한 최근 첨단 공학 세라믹의 방전가 공의 연구는 증가하고 있는 추세이다 $[5,6]$.

Micro-EDM에서 사용되는 Tools(전극) 제작을 위해 와이어 방전연삭(Wire Electronic Discharge Grinding; WEDG)방법을 이용한다. 이러한 WEDG 시스템을 구축하게 되면 전극을 주축에 장착할 때 발생하는 척 킹 오차(Chucking error), 런아웃(Run-out), 공구축의 이동(Shift) 및 기울어짐(Tilting)등의 오차로부터 영향 을 최소화하게 되므로 미세가공이 가능하다[7]. 특히 정밀가공을 위해선 $\mathrm{WEDG}$ 의 장력 조절이 매우 중요 한 요소이며, 장력 제어 방법으로 서보모터 속도제어, 파우더 브레이크, ER(Electro- Rheological) 브레이크 등이 있다. 하지만 기존의 방법들은 로드셀 $(\mathrm{Load}$ cell)이나 덴서롤(Dancer roll)과 같이 장력을 측정하 는 센서가 필요함으로 기구부의 소형화가 어렵다는 단점이 있다[8].

따라서, 본 연구에서는 촉매기상합성법으로 제조된 순도 $90 \%$ 의 다중벽 탄소나노튜브(CNT)와 알루미나 $\left(\mathrm{Al}_{2} \mathrm{O}_{3}\right)$ 를 이용하여 제조된 알루미나 탄소나노튜브 복 합체를 제조하였다. CNT 함유량에 따른 소재특성 평 가를 통해서 최적으로 방전가공이 가능한 소재를 선 정 하였다. 포토 인터럽터(Photo interrupter)를 이용 하여 소형의 WEDG 시스템을 제작하여, 전극을 미 세가공 하였다. 미세전극을 이용하여 $\mathrm{Al}_{2} \mathrm{O}_{3} / \mathrm{CNTs}$ 복 합소재에 방전조건을 변화하여 가공하였다. 가공 특 성평가는 전계방사 주사전자현미경(Field Emission Scanning Electron Microscope, FE-SEM)을 이용하 여 전극의 형상 및 가공 후 가공 정밀도와 가공면의
상태를 관찰하였으며 이를 바탕으로 마이크로 방전 가공의 특성을 살펴보고자 한다.

\section{2. 실험장치 및 방법}

\section{1. $\mathrm{Al}_{2} \mathrm{O}_{3} / \mathrm{CNTs}$ 하이브리드 복합소재 제조}

본 연구 $\mathrm{Al}_{2} \mathrm{O}_{3} / \mathrm{CNTs}$ 하이브리드복합소재 제조에 사용된 알루미나는 스미토모사의 이소결성 알루미나 인 AES-11이다. AES-11은 입도분포가 500 1000 $\mathrm{nm}$ 급으로 알루미나 분말이 미세하며, 소결조제로서 $\mathrm{MgO}$ 가 0.1 wt.\% 함유되어 소결이 용이한 장점이 있다. AES-11분말을 알코올에서 볼 밀(Ball mill) 분 산 처리하여 알루미나 분말입자를 충분히 사전 분산 시켜 CNT와의 균일분산이 될 수 있도록 한 후 $\mathrm{CNT}$ 와 혼합하여 사용하였다. 알루미나 입자의 분산 은 직경 $10 \mathrm{~mm}$ 의 지르코니아 $\left(\mathrm{ZrO}_{2}\right)$ 볼을 이용하였으 며 분산조건은 $240 \mathrm{rpm}, 24$ 시간 동안 볼 밀 분산처 리 하였다.

CNT는 (주)어플라이드카본나노(Applied Carbon Nano Technology Co., Ltd, Pohang, Korea)에서 제조 된 순도 $90 \%$ 의 multi-wall CNT로서 알루미나의 소 결조제인 $\mathrm{MgO}$ 를 $\mathrm{CNT}$ 의 촉매로 사용하여 알루미나 탄소나노복합재의 소결성을 개선할 수 있도록 CNT 합성 촉매를 설계 제조한 후 CNT를 합성하였다. 합 성된 $\mathrm{CNT}$ 는 분산성을 개선하기 위하여 직경 10 $\mathrm{mm}$ 의 지르코니아 $\left(\mathrm{ZrO}_{2}\right)$ 볼을 이용하여 24 시간 동안 볼밀 사전처리를 통하여 충분히 풀어준 후 초음파 분산 기(Sonosmasher ULH-700Watts, Young Wha Scientific Co., Ltd., Korea)로 분산하여 알코올 내에서 CNT의 충분한 분산이 이루어지도록 하였다. 이를 건조하여 분산성이 강화된 $\mathrm{CNT}$ 분말을 제조한 후 알루미나 탄소나노복합분말 제조에 사용하였다.

$\mathrm{Al}_{2} \mathrm{O}_{3} / \mathrm{CNTs}$ 복합재는 고에너지볼밀인 내부용량 6 리터의 어트리션볼밀(attrition ball mill)을 이용하여 복합화 하였다. 고에너지볼밀에 직경 $5 \mathrm{~mm}$ 의 $\mathrm{SUS304}$ 볼을 $15 \mathrm{~kg}$ 을 장입한 후 사전에 충분히 분 산된 $\mathrm{AES}-11$ 과 $\mathrm{CNT}$ 를 복합하고자 하는 조성비율에 맞게 전체 중량이 $1 \mathrm{~kg}$ 이 되도록 중량비율로 계량한 후 장입하여 제조하였다.

방전가공을 위한 $\mathrm{Al}_{2} \mathrm{O}_{3} / \mathrm{CNTs}$ 성형재는 Spark Plasma Sintering(SPS)법으로 제조하였다. SPS법은 상, 하부 펀치 및 실린더로 구성된 그라파이트(Graphite) 


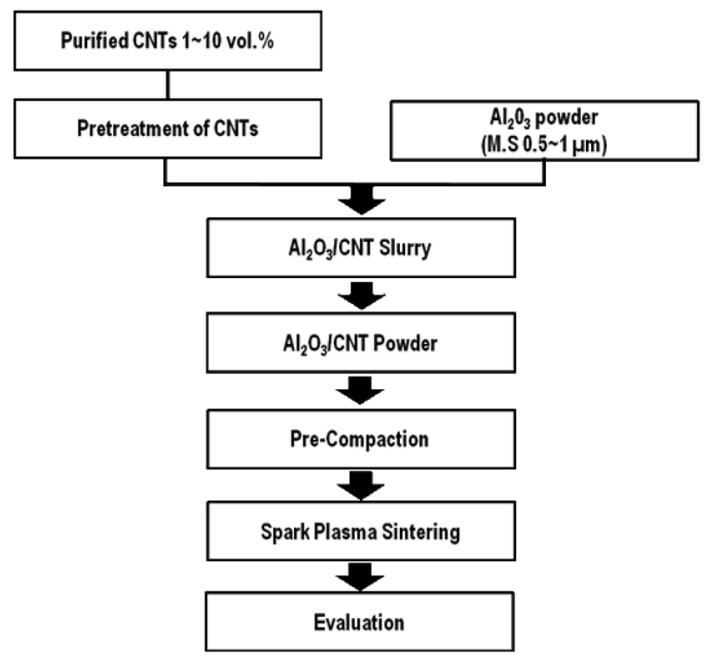

Fig. 1. Schematic diagram showing the fabrication procedures of the $\mathrm{Al}_{2} \mathrm{O}_{3} /$ CNTs composites.

또는 초경몰드를 이용하여 분말을 성형하는 공정으 로 설비 내 분위기 조절이 가능하고 급속한 가열 및 냉각이 가능하여 단시간에 분말을 성형할 수 있는 장 점을 가지고 있다.

$\mathrm{Al}_{2} \mathrm{O}_{3} / \mathrm{CNTs}$ 복합분말을 내경 $20 \mathrm{~mm}$, 외경 60 $\mathrm{mm}$, 높이 $50 \mathrm{~mm}$ 의 그라파이트 실린더몰드에 장입 하여 성형재를 제조하였다. 초기 원료 장입상태에 따 라 제조되는 성형재의 형상 및 그라파이트 몰드의 안 정성이 달라질 수 있기 때문에 $\mathrm{Al}_{2} \mathrm{O}_{3} / \mathrm{CNTs}$ 복합분 말이 장입된 그라파이트 몰드를 프레스 상온가압을 통해 Pre-compaction 시킨 후 SPS 설비에 안치한 후 SPS성형을 실시하였다.

제조조건은 SPS 소결온도 $1380^{\circ} \mathrm{C}$, 가압력 40 $\mathrm{MPa}, 10$ 분 동안 가압 유지시켜 $\mathrm{Al}_{2} \mathrm{O}_{3} / \mathrm{CNTs}$ 복합 성형재를 제조하였다. 복합재료 제조공정의 흐름도를 그림 1에 나타내었다. 위를 바탕으로 CNT 함유량에 따른 소재특성을 파악하여 방전가공이 가장 적합한 소재를 선정하여 방전가공을 하였다.

\section{2. 마이크로 방전 실험장치 구성}

그림 2는 실험에 사용된 마이크로 방전가공기 (Hyper 15, Hybrid Precision Co.)와 일체형의 와이어 방전연삭장치이다. RC-type의 전원공급장치에 의하여 방전이 생성되며, 최대 이송거리는 $130 \mathrm{~mm} \times 75 \mathrm{~mm}$ $\times 80 \mathrm{~mm}$ 이고, $\mathrm{x}, \mathrm{y}$ 그리고 $\mathrm{z}$ 방향의 Resolution은 $0.1 \mu \mathrm{m}$ 를 가진다.

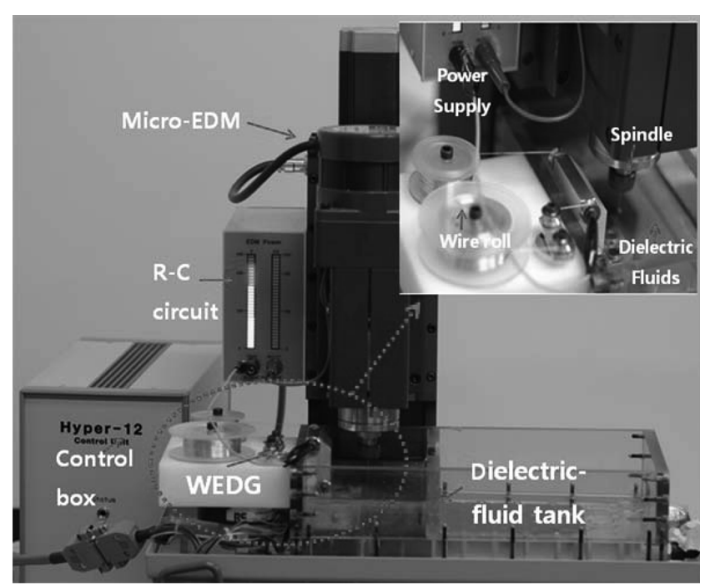

Fig. 2. Photo view of micro-EDM machine and WEDG device.

Table 1. Material properties of the electrode for MicroEDM

\begin{tabular}{lc}
\hline \hline \multicolumn{1}{c}{ Electrode material } & Tungsten $(\mathrm{W})$ \\
\hline Density $\left(\mathrm{g} / \mathrm{cm}^{3}\right)$ & 19.3 \\
Thermal conductivity $(\mathrm{W} / \mathrm{m} \cdot \mathrm{K})$ & 163.3 \\
Electrical resistivity $(\mathrm{i} \cdot \mathrm{cm})$ & 5.5 \\
Hardness & HRA66 \\
\hline
\end{tabular}

Table 2. Main specification of wire electrode for WEDG Device

\begin{tabular}{ll}
\hline \multicolumn{1}{c}{ Wire grade } & Brass wire \\
\hline Diameter $(\mathrm{mm})$ & 0.2 \\
Breaking load $(\mathrm{Kg})$ & $3.08-3.27$ \\
Tensile strength $(\mathrm{Kg} / \mathrm{mf})$ & $100-115$ \\
Diameter tolerance $(\mathrm{mm})$ & \pm 0.001 \\
\hline
\end{tabular}

$\mathrm{WEDG}$ 시스템에서 가장 중요한 요소는 와이어 (wire)가 주변 환경 변화에 원활하게 대응 가능하도 록 와이어의 장력을 제어하는 기술로서, 본 연구에서 는 장력을 포토 커플러(Photo coupler)의 일종인 포 토 인터럽터(Photo interruptor) 를 이용하여 장력을 일정하게 제어하였다.

미세전극 가공 시 사용된 전극은 $500 \mu \mathrm{m}$ 직경의 로드(rod)형 텅스텐(W)이며, 중요 물성치는 표 1과 같다. 방전가공유는 독일의 Oelheld사의 Dielectric IME-MH를 사용하였고 전극 가공 시 사용된 와이어 (PAPS CUT-S, Pungkuk Co., Ltd)는 표준 황동와이 어로 와이어 규격을 표 2에 나타내었다. 


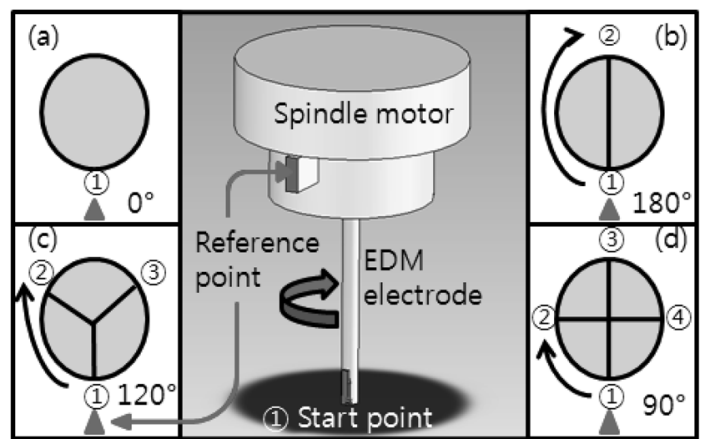

Fig. 3. Evaluating method for run-out effect according to various setting angle (a) $0^{\circ}$, (b) $180^{\circ}$, (c) $120^{\circ}$ and (d) $90^{\circ}$.

\section{3. 실험방법}

미세전극 가공을 위해 방전가공의 역극성(Reverse polarity)을 이용하여 WEDG를 수행하였다. 이때 가 공에 영향을 많이 끼치는 요인 중 하나인 와이어 회 전속도에 따른 가공상태를 평가하였다. 가공조건으로 는 방전가공유를 사용하여 Voltage 120(V), Resistance $2(\Omega)$ 으로 설정하여 와이어 주행속도를 $0.5,0.75,1.0$ $\mathrm{RPM}$ 의 속도로 주행하여 실험을 수행하였다.

전극의 회전에 의한 런아웃(Run-out)을 최소화하는 것이 매우 중요하다. 런아웃을 해결하기 위한 방안으 로, 그림 3에 나타낸 바와 같이 스핀들 축에 기준점 (Reference point)을 설정하여 오차를 최소화하는 방 법을 고안하였다. 기준점으로부터 임의의 회전각 $0^{\circ}$, $180^{\circ}, 120^{\circ}$, 및 $90^{\circ}$ 의 변화에 따른 전극의 고정 회전 수와 런아웃의 상관관계를 조사하였다.

$\mathrm{WEDG}$ 를 토대로 최적의 조건으로 가공된 미세전 극으로 $\mathrm{Al}_{2} \mathrm{O}_{3} / \mathrm{CNT}$ 소재를 마이크로 방전가공 하였 다. 가공 시 Voltage $(\mathrm{V})$ 와 Capacitance $(\mathrm{C})$ 를 변화하 여 방전에 따른 가공 특성을 알아 보았다. 방전가공 시 조건은 표 3에 나타내었다. 전계방사 주사전자현 미경을 이용하여 전극 형상 및 구멍 직경을 측정하 였고, 이를 통하여 $\mathrm{Al}_{2} \mathrm{O}_{3} / \mathrm{CNTs}$ 하이브리드소재의 방 전가공 특성을 알아 보았다.
Table 3. Machining parameters for micro-hole machining in the micro-EDM

\begin{tabular}{ll}
\hline \hline \multicolumn{2}{c}{ RC circuit } \\
\hline Voltage $(\mathrm{V})$ & 150,200 \\
Capacitance $(\mathrm{pF})$ & 1000,10000 \\
Resistance $(\Omega)$ & 1 \\
Feed rate $(\mu \mathrm{m} / \mathrm{sec})$ & 1 \\
Spindle speed $(\mathrm{rpm})$ & 1000 \\
\hline
\end{tabular}

\section{3. 실험결과 및 고찰}

\section{1. $\mathrm{Al}_{2} \mathrm{O}_{3} / \mathrm{CNTs}$ 하이브리드소재의 특성}

그림 1 의 과정을 통해서 만든 $\mathrm{Al}_{2} \mathrm{O}_{3} / \mathrm{CNT} 1,3$, 5,10 vol.\% 소재의 CNT 함유량에 따른 소재 특성 을 분석하여 표 4에 나타내었다. 표 4를 살펴보면 전기전도도는 $\mathrm{CNT}$ 함유량이 증가 할수록 증가하였 다. 이는 $\mathrm{CNT}$ 가 우수한 전기전도도의 성질을 지니 므로, $\mathrm{CNT}$ 함유량이 증가 함에 따라 전체적인 전기 전도도를 증가하는 경향이 있었다. 경도는 $\mathrm{CNT}$ 함 유량이 증가 할수록 감소하는 경향을 보였다 [9]. 밀 도와 상대밀도는 CNT 함유량이 많아질수록 낮아지 는 경향이 있었다. CNT가 나노튜브 형태이므로 $\mathrm{CNT}$ 함유량이 증가할수록 밀도가 감소했다. 방전가 공에서 가장 중요한 요소는 전기전도도 이므로 $\mathrm{Al}_{2} \mathrm{O}_{3} / \mathrm{CNTs} 10$ vol.\%를 방전가공을 위한 소재로 선 정하였다.

\subsection{WEDG에 의한 가공특성}

그림 4는 와이어의 주행속도에 따른 가공특성을 알 아보기 위해서, $0.5,0.75,1.0 \mathrm{RPM}$ 으로 변화 시켜 가공한 후의 표면 모습이다. (a)는 $0.5 \mathrm{RPM}$ 의 주행 속도로 가공한 전극형상으로서, 용융 재응고층(Recast layer)의 크기가 상당히 큰 것을 볼 수 있다. (b)와 (c)는 각각 $0.75,1.0 \mathrm{RPM}$ 으로 가공했으며 (c)가 (b)에 비해 표면이 양호한 결과를 얻었다. 이는 가공

Table 4. Properties of the electrical conductivity, density and hardness for $\mathrm{Al}_{2} \mathrm{O}_{3} / \mathrm{CNTs}$ hybrid materials

\begin{tabular}{cccc}
\hline \hline Materials & $\begin{array}{c}\text { Electrical Conductivity } \\
(1 / \Omega \cdot \mathrm{cm})\end{array}$ & $\begin{array}{c}\text { Hardness } \\
(\mathrm{Hv})\end{array}$ & $\begin{array}{c}\text { Density }\left(\mathrm{g} / \mathrm{cm}^{3}\right), \\
(\text { Relative density }(\%))\end{array}$ \\
\hline $\mathrm{Al}_{2} \mathrm{O}_{3} / \mathrm{CNTs} 1 \mathrm{vol} \%$ & $1.13 \mathrm{E}-09$ & 1960.34 & $3.841(99.244)$ \\
$\mathrm{Al}_{2} \mathrm{O}_{3} / \mathrm{CNTS} 5$ vol.\% & $1.82 \mathrm{E}-06$ & 1733.28 & $3.805(96.239)$ \\
$\mathrm{Al}_{2} \mathrm{O}_{3} / \mathrm{CNTs} 10 \mathrm{vol} \%$ & $5.67 \mathrm{E}-05$ & 1566 & $3.758(93.499)$ \\
\hline
\end{tabular}




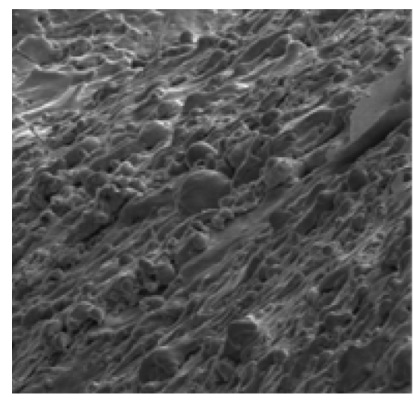

(a)

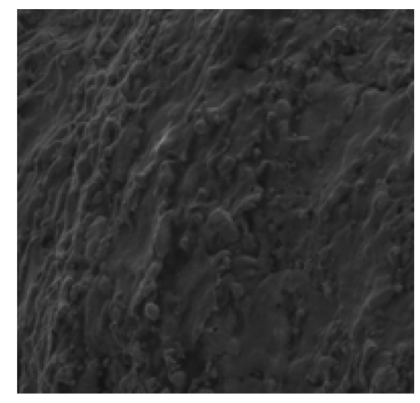

(b)

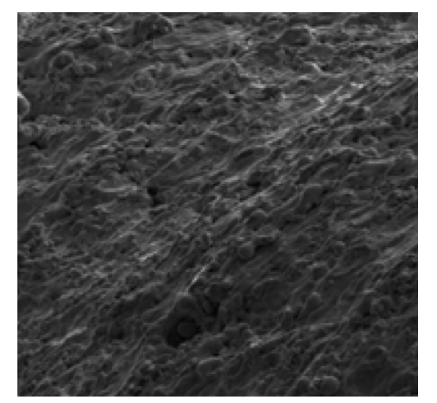

(c)

Fig. 4. Surface characteristics of EDM electrode according to wire running speed (a) 0.5 RPM, (b) 0.75 RPM and (c) 1.0 RPM.

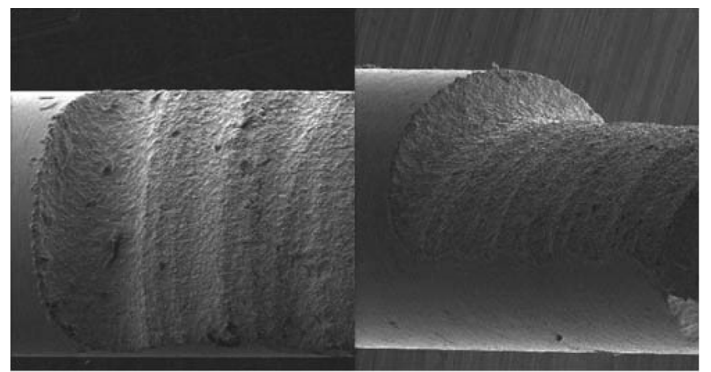

(a) $0^{\circ}$, 1st machining

(b) $180^{\circ}$, 2nd machining

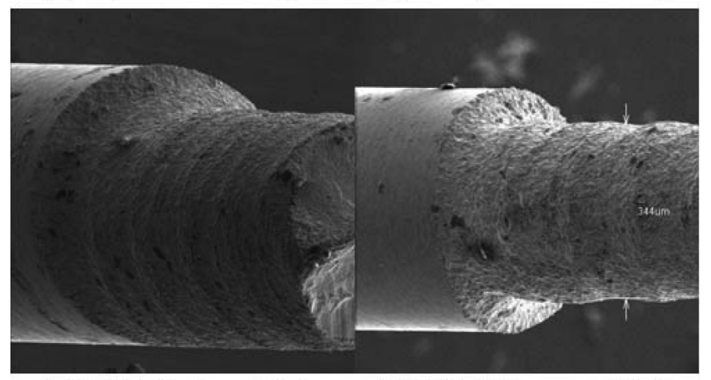

(c) $120^{\circ}$, 3nd machining (d) $90^{\circ}, 4$ times machining

Fig. 5. Surface characteristics of electrode according to electrode setting angle (a) $0^{\circ}$, (b) $180^{\circ}$, (c) $120^{\circ}$ and (d) $90^{\circ}$.

중에 와이어의 주행 속도가 빠르면 가공표면에 새로 운 와이어 전극의 공급이 더 원활하므로 방전이 보 다 안정적이기 때문이다[10].

그림 5에서는 Micro-EDM용 텅스텐 전극이 각도 에 따른 가공 특성을 나타낸 그림이다. (a)의 $0^{\circ}$ 는 전극을 단순히 한 지점에서 한번 가공한 것이고 (b) 의 $180^{\circ}$ 는 1 회 전극을 깎고 2 회째 가공 시 전극을 $180^{\circ}$ 로 비틀어서 가공하였다. (c)와 (d)의 $120^{\circ}, 90^{\circ}$ 역시 전극을 비틀어서 각각 3회와 4회 가공한 모습 을 보여준다. 사진으로 보이듯이 점점 전극의 가공 형상이 한쪽으로 치우치지 않고 상당히 좋아지는 것
을 볼 수 있다. 이와 같은 이유는 $\mathrm{EDM}$ 전극이 스핀 들 회전으로 인하여 런아웃이 발생하게 된다. 그로 인해 1 번 가공 하게 되면 (a)와 같이 전극의 한쪽만 가공되는 비대칭 가공이 된다. 이를 보완 하고자 가 공횟수를 증가하는 방법과 스핀들의 시작위치를 일 정하게 비틀어서 보다 향상된 표면품위, 형상 정도, 런아웃 최소화를 가능하게 하였다. 마이크로 가공을 위해 그림 5 의 (d)의 $90^{\circ}$ 의 4 번의 전극회전을 통해 가공된 미세전극을 이용하여 마이크로 방전가공을 하 였다.

\section{3. 마이크로 방전가공 특성}

그림 6 은 $\mathrm{Al}_{2} \mathrm{O}_{3} / \mathrm{CNTs}$ 복합재료를 방전가공 한 후 $\mathrm{FE}-\mathrm{SEM}$ 으로 측정 결과이다. 그림 $6(\mathrm{a})$ 는 $150 \mathrm{~V}$, $1000 \mathrm{pF}$ 이며, (b)는 $200 \mathrm{~V}, 10000 \mathrm{pF}$ 의 조건하에 서 방전가공을 수행하였다. 방전가공 후 구멍의 직경 으로는 $500 \mu \mathrm{m}, 621 \mu \mathrm{m}$ 으로 나타났다. 이는 방전 가공 시 투입되는 단발 에너지는 $1 / 2 \mathrm{CV}^{2}$ 으로 $\mathrm{V}$ 와 $\mathrm{C}$ 의 값이 클수록 에너지가 증가하며, 가공표면 및 형 상에 영항을 주었다. 이번 실험의 4 가지 조건 중 에너지를 가장 많이 투입했던 (b) 조건이 가장 적게 투입 한 (a) 조건 보다 가공 후 직경이 약 $121 \mu \mathrm{m}$ 크게 나타났다. 또한 가공단면적을 비교하면 상대적 으로 투입된 에너지가 적은 (a) 조건일 때 재결정되 는 입자의 크기가 작음을 거시적으로 알 수 있었다. 따라서 이번 연구에서 $150 \mathrm{~V}, 1000 \mathrm{pF}$ 의 방전조건 에서 정밀도와 표면정도가 다른 조건에 비해 우수 하 였다. 또한 위 결과로부터 방전가공 시 에너지를 최 소한으로 투입하여 가공정밀도를 향상 시킬 수 있다. 하지만 전도성 세라믹소재는 금속재료만큼 전기전도 도가 우수하지 못하여 금속 가공 시 보다 많은 에너 


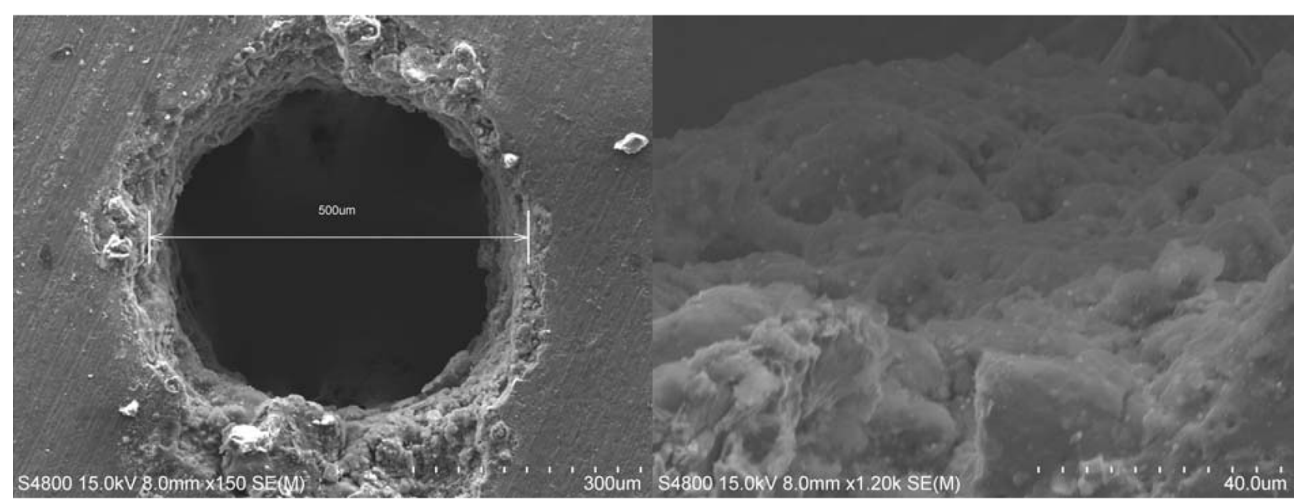

(a)

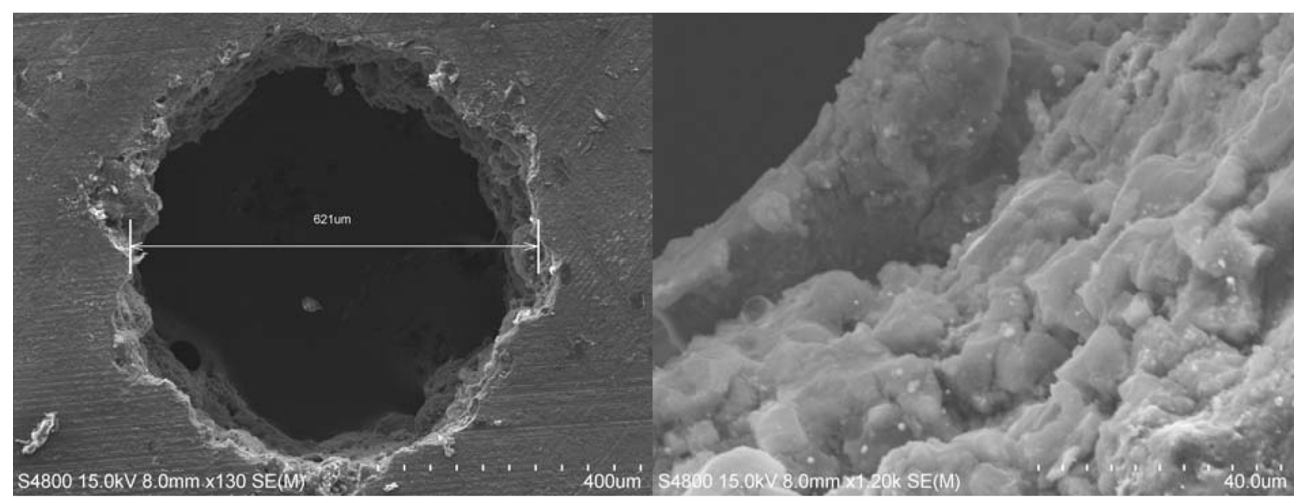

(b)

Fig. 6. Picture of the holes and surface quality using the FE-SEM after micro-EDM; (a) $150 \mathrm{~V}, 1000 \mathrm{pF}$ and (b) $200 \mathrm{~V}, 10000 \mathrm{pF}$.

지를 투입하였다[11]. 이 결과 가공정밀도는 많이 저 하되었지만 세라믹소재의 방전가공의 가능성을 알아 봄으로써 정밀가공의 가능성을 알 수가 있었다.

\section{4. 결 론}

본 연구에서는 나노 분말재료를 이용하여 SPS공정 을 통해 $\mathrm{Al}_{2} \mathrm{O}_{3} / \mathrm{CNTs}$ 나노복합 소재를 제작하였고, 방전가공을 위한 최적의 CNT 함유량을 선정하여 마 이크로 방전가공을 수행하여 다음과 같은 결론을 얻 었다.

$\mathrm{Al}_{2} \mathrm{O}_{3} / \mathrm{CNT}$ 1, 3, 5, 10 vol.\% 소재의 CNT 함 유량에 따른 소재특성에서 CNT 함유량이 증가 할수 록 전기전도도가 향상됨을 알 수 있었다. 전기전도도 는 방전가공에서 중요한 요소로써 이번 연구에서는 $\mathrm{Al}_{2} \mathrm{O}_{3} / \mathrm{CNT} 10$ vol. \%가 가장 우수하였다. 마이크로 방전가공을 위해서 $\mathrm{WEDG}$ 가공이 필수적으로 필요
하고, 이때 새롭게 제안한 방법 중 기준점을 중심으 로 $90^{\circ}$ 로 4 번 가공한 것이 런아웃을 최소화 할 수 있었다. 또한 와이어 주행속도가 증가 할수록 전극의 표면정도는 좋아졌고 $1 \mathrm{RPM}$ 일 때 표면품위가 가장 좋았다. $\mathrm{Al}_{2} \mathrm{O}_{3} / \mathrm{CNT} 10 \mathrm{vol} \%$ 를 방전가공시 투입되 는 방전 에너지가 작은 조건에서 가공정밀도가 더 우 수 하였으며, 표면 거칠기도 적음을 알 수 있었다.

이상의 결과로부터, $\mathrm{Al}_{2} \mathrm{O}_{3} / \mathrm{CNT}$ 복합소재의 방전가 공 가능성을 확인 할 수 있었고 기존의 전통적인 가 공으로 한계를 지닌 3 차원가공과 정밀가공 실현에 유 용한 정보로 활용될 것으로 기대된다.

\section{감사의 글}

본 연구는 한국연구재단을 통해 교육과학기술부의 선도연구센터육성사업 학제간융합분야 (NCRC)(20100008-277)와 부산대학교 자유과제 학술연구비(2년)에 
의하여 연구되었습니다.

\section{참고문헌}

[1] S. Agarwal and P. V. Rao: Int. J. Mach. Tools Manuf., 48 (2008) 698.

[2] W. A. Curtin and B. W. Sheldon: Mater. Today., 7 (2004) 44.

[3] R. H. Baughman, A. A. Zakhidov and W. A. de Heer: Science., 297 (2002) 787.

[4] M. R. Falvo, G. J. Clary, R. M. Taylor, II, V. Chi, F. P. Brooks, Jr, S. Washburn and R. Superfine: Nature., 389 (1997) 582.

[5] S. Put, J. Vleugels, O. V. Biest, C. Trueman and J.
Huddleston: Br. Ceram. Trans., 5 (2001) 207.

[6] C.-C. Liu: Mater. Sci. Eng. A-Struct. Mater. Prop. Microstruct. Process., 363 (2003) 221.

[7] S. J. Park, H. M. Ahn and K. S. Lee: Trans. Korea. Soc. Mach. Tool Eng., 14 (2005) 13.

[8] T. A. Spedding and Z. Q. Wang: J. Mater. Process. Techn., 69 (1997) 18.

[9] G. D. Zhan and A. K. Mukherjee: Int. J. Appl. Ceram. Techn., 1 (2004) 161.

[10] S. H. Lee and X. P. Li: J. Mater. Process. Techn., 115 (2001) 344.

[11] H. S. Tak, C. S. Ha, D. H Kim, H. J. Lee, H. J. Lee and M. C. Kang: Trans. Nonferrous Met. China., 19 (2009) 114. 